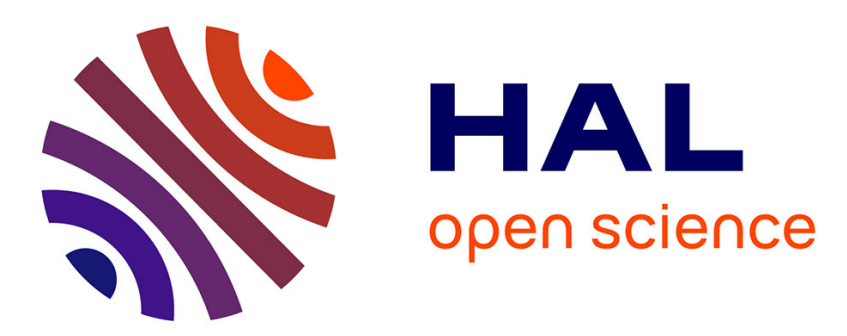

\title{
Is migration important for regional convergence? Comparative evidence for Norwegian and Swedish counties, 1980-2000
}

\author{
Stein Østbye, Olle Westerlund
}

\section{- To cite this version:}

Stein Østbye, Olle Westerlund. Is migration important for regional convergence? Comparative evidence for Norwegian and Swedish counties, 1980-2000. Regional Studies, 2007, 41 (07), pp.901-915. 10.1080/00343400601142761 . hal-00514655

\section{HAL Id: hal-00514655 \\ https://hal.science/hal-00514655}

Submitted on 3 Sep 2010

HAL is a multi-disciplinary open access archive for the deposit and dissemination of scientific research documents, whether they are published or not. The documents may come from teaching and research institutions in France or abroad, or from public or private research centers.
L'archive ouverte pluridisciplinaire HAL, est destinée au dépôt et à la diffusion de documents scientifiques de niveau recherche, publiés ou non, émanant des établissements d'enseignement et de recherche français ou étrangers, des laboratoires publics ou privés. 


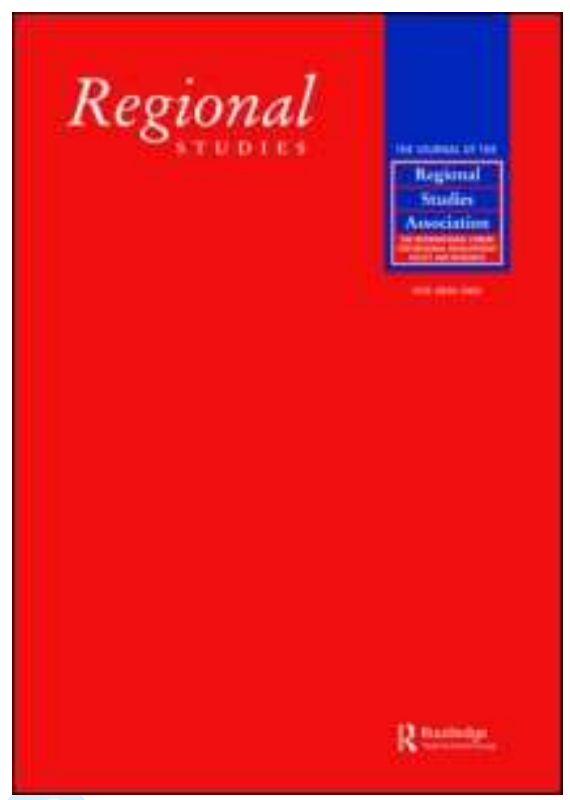

\section{Is migration important for regional convergence? Comparative evidence for Norwegian and Swedish counties, 1980-2000}

\begin{tabular}{|c|l|}
\hline Journal: & Regional Studies \\
\hline Manuscript ID: & CRES-2005-0202.R2 \\
\hline Manuscript Type: & Main Section \\
\hline JEL codes: & $\begin{array}{l}\text { J61 - Geographic Labor Mobility } \mid \text { Immigrant Workers < J6 - Mobility, } \\
\text { Enemployment, and Vacancies < J - Labor and Demographic } \\
\text { Development, and Changes < R1 - General Regional Economics < R } \\
\text { - Urban, Rural, and Regional Economics, R23 - Regional } \\
\text { Migration|Regional Labor Markets|Population < R2 - Household } \\
\text { Analysis < R - Urban, Rural, and Regional Economics }\end{array}$ \\
\hline Keywords: & $\begin{array}{l}\text { regional growth, regional migration, convergence, comparative } \\
\text { study, Nordic countries }\end{array}$ \\
\hline \hline
\end{tabular}

\section{SCHOLARONE Manuscripts}




\title{
Is migration important for regional convergence? Comparative evidence for Norwegian and Swedish counties, 1980-2000
}

\author{
By \\ Stein Østbye ${ }^{*}$ and Olle Westerlund ${ }^{* *}$ \\ * Department of Economics, University of Troms $\varnothing$, Norway (stein.ostbye@nfh.uit.no) \\ ** Department of Economics, University of Umeå, Sweden (olle.westerlund@econ.umu.se)
}

\begin{abstract}
Regional convergence studies have relied on net migration data in assessing the impact of migration. With heterogeneous labour, the implied symmetrical treatment of immigration and emigration cannot be justified a priori. Because of heterogeneity among migrants, gross migration flows may lead to considerable interregional redistribution of human capital even when net migration is zero. Moreover, the effects of regional economic conditions on gross in- and out-migration flows may not be symmetric. In this comparative study of regional growth and migration, the net and the gross migration approaches are compared. The results confirm ex post that the net approach cannot be justified and, despite Sweden and Norway being similar in many ways, migration has very different effects on convergence in these two countries.
\end{abstract}




\section{Introduction}

One of the substantial features that often distinguish models of regional economics from models of international economics is the presence or absence of migration, reflecting the view that migration between countries is unimportant in comparison to internal migration within one country. ${ }^{1}$ Accordingly, regional economic growth studies should allow for internal migration effects and be based on models that take into account the possible interdependence between migration and growth. In this study, the effect of migration on economic convergence of regions is examined. Regional convergence is a major issue for European integration and for obtaining local political support for economic integration in general. The empirical analysis is based on a panel data set for Norwegian and Swedish counties, and the results are interpreted in terms of a neoclassical model. ${ }^{2}$

In the neoclassical growth model, diminishing returns to scale imply that out of steady state, regions with low capital intensity will grow faster than those with high intensity, ceteris paribus. When labour is homogeneous, migration adds to this convergence process by increasing the capital intensity in regions with net out-migration and decreasing it in regions with net in-migration. When labour is heterogeneous, the effect of migration on convergence is unclear as the migrants embody human capital. If the migrants are more productive than the non-migrants, the loss in human capital per worker may outweigh the increase in physical capital per worker and slow down growth. Moreover, if the migrants possess more human capital than workers in the host region, the increase in human capital per worker in the host region may dominate the effect of the decrease in physical capital per worker. Migration will then boost growth in the host region and thereby counteract convergence between regions, and may even result in economic divergence. The ambiguous effect of migration on growth 
and convergence, once labour heterogeneity is taken into account, has been recognized as important in order to mitigate the gap between theory and previous empirical research (Dolado, Goria and Ichino, 1993, Friedberg and Hunt, 1995). However, there is some skepticism as to whether the shifts in human capital are large enough to fully account for the findings of these earlier studies (Shioji, 2001).

Our work can be compared with that of Aronsson, Lundberg and Wikström (2001), henceforth ALW, and to the often cited studies on Japan, U.S. and European regions by Barro and Sala-i-Martin (as presented in Barro and Sala-i-Martin, 2004, henceforth BS). ALW study migration and convergence based on Swedish data at the same spatial resolution as we do (i.e. county level), but they only estimate the reduced form of a growth and a net-migration equation and do not examine the relationship between net-migration and the convergence process. However, they find that net-migration is inversely related to regional unemployment. BS estimate the structural form as do we, but they do it at a coarser regional level of aggregation (U.S. States, Japanese prefectures and European regions) which is closer to the Nordic countries than to the Nordic regions. Generally, the findings in BS indicate that net migration responds in the expected direction to regional differences in per capita income. The results are, however, insignificant in most cases for the European regions and the magnitudes of the estimated effects of per-capita incomes on net migration are small. Moreover, they find no strong evidence of a positive correlation between the income elasticity of net-migration and the speed of convergence. In comparison with both ALW and BS, we take the analysis further in several important respects. First, we recognize that in- and out-migration may have very different impacts on regional growth for the reasons explained above. Using net migration instead of gross migration could, therefore, yield misleading results. Further, the estimation of a net migration function is based on restrictive, and probably unwarranted, 
assumptions. The independent variables are assumed to have symmetric effects on gross inmigration and out-migration, respectively. ${ }^{3}$ For all these reasons gross migration is preferable to net migration and will, therefore, be used in this study. To the best of our knowledge, this is the first time an analysis of gross migration flows has been integrated into a growth convergence study. Secondly, although both ALW and BS use instrumental variable techniques in some of their model specifications, there could be serious problems with weak instruments (see, e.g., Staiger and Stock, 1997). Recent work on dynamic panel estimation of growth equations strongly suggests that system GMM should be considered in models with predetermined or endogeneous regressors based on small samples, where instrumental variable techniques are called for (see Bond et al., 2001). Using a dynamic panel data setup, we are in a position to follow this recommendation. Thirdly, given the recent attention to invalid inference in regression models with spatial dependence in the residuals (e.g., Badinger et al., 2004, on European regions at the NUTS2 level), it is interesting to investigate the spatial properties of our Nordic data and the residuals from the regressions to assess the extent of this potential problem.

Anticipating the results, our main findings are: migration has an effect on the rate of convergence. There are differences between the two countries we study. Gross migration adds to convergence in Sweden, whereas it counteracts convergence in Norway. The major part of these effects are due to migration between counties that are different with respect to human capital. Hence, the findings are consistent with brain-gain in Sweden and brain-drain in Norway, from the perspective of the lagging regions. Using net migration instead of gross migration does not give the same results, in the case of Norway not even in a qualitative sense. 
The paper is organized into five sections. Section 2 outlines the conceptual model. Data is presented in Section 3, and estimation issues are discussed in Section 4. Section 5 concludes.

\section{The conceptual model}

As in all empirical convergence studies, the systematic part of the equation explaining the current output per capita (or the per capita output growth rate) is hypothesized to depend on the lagged level of the dependent variable. Ceteris paribus, the parameter (beta) on the lagged dependent variable is expected to be negative. Within a Schumpeterian framework, this is because of differences in technology that make the potential for imitation vary (the lagged dependent variable is often used as proxy for technological level). Within a neoclassical framework, it is because of constant returns to scale technology that lead to diminishing returns for each separate input. ${ }^{4}$ When regional data is used, the ceteris paribus condition is sometimes assumed to be true without introducing other conditioning covariates or allowing for individual effects. The neoclassical argument for this is that the regions within a country are sufficiently similar in terms of technology, preferences and institutions so that they can be expected to approach approximately the same long term growth trajectory (the same steadystate). If the beta is found to be significant and negative ex post, without further conditioning covariates or individual effects, the case is referred to as an absolute beta-convergence.

Within the neoclassical approach, the approximate speed of the convergence process may be deduced from a negative estimate of the beta parameter. The lower the beta estimate is in absolute value, the higher is the estimated rate of convergence. ${ }^{5}$ 
If migration does not change the regional distribution of human capital, we would expect the estimated rate of convergence to fall when migration is added to the set of covariates. The reasoning for this goes as follows (see BS p. 492): when we keep migration constant, as we do when it is added to the set of independent variable in the regression, we ignore migration as a potential important source of convergence. When we kick out migration from the regression, we allow its effect to influence the estimate of the convergence rate. As migration is expected to contribute to convergence, the rate of convergence should fall.

As mentioned in the introduction, when migration changes not only the number of workers but also the regional distribution of human capital, there is no clear prediction. We may distinguish between two possibilities. If migration leads to an increase in human capital in the lagging regions and a decrease in the leading regions, a situation sometimes referred to as brain-gain in the literature on international labour migration, the qualitative effect of migration on convergence will remain positive and the effect will be stronger. If, on the other hand, migration leads to an increase in human capital in the leading regions at the expense of the lagging regions, a situation referred to as brain-drain, the quantity effect through the change in the number of people will be counteracted. If this brain-drain effect is sufficiently strong, it may dominate and lead to migration having a negative net effect on convergence. Further information on the brain-drain versus brain-gain issue may be obtained by adding human capital to the set of covariates. If we keep human capital constant, we would expect the effect of migration on convergence to be much smaller in cases where the brain-drain or the brain-gain effects were important. This is because these effects work between regions with unequal endowments of human capital. 
Introducing some notation, the systematic part of the growth equation with the full set of covariates may be summarized as

$$
y_{i, t}=f\left(y_{i, t-1}, n m_{i, t}, x_{1, i, t-1}, \text { year }_{t}\right)
$$

for a net-migration specification, and

$$
y_{i, t}=f\left(y_{i, t-1}, \text { im }_{i, t}, \text { om }_{i, t} x_{1, i, t-1}, \text { year }_{t}\right)
$$

for a gross-migration specification. The symbols used are $y$ for output per capita with subscript $t-1$ referring to the start of the time period, $\mathrm{nm}$ for the net-migration rate and $\mathrm{im}$ and $o m$ for gross in and out migration rates (between $t-1$ and $t$ ). Human capital is denoted $x_{1}$. We have also added a time dummy to allow for exogeneous shifts due to technological change from one period to the next. The specification (2.1) may be regarded as a special case of (2.2), obtained by imposing the restriction that in- and out-migration work symmetrically. Hence, we may assess ex post whether the net-migration specification can be justified as a reduced form of the gross-migration specification by simply comparing the results based on the two specifications.

Although our primary interest is in how migration affects convergence, we cannot completely ignore how migration is determined for at least two reasons. The first is that migration may not be exogenous in the growth equation, but may be correlated with the disturbance term. If there are determinants that can be expected to affect migration, but not directly output per capita, they may serve as instruments for migration in the growth equation. It is, therefore, of interest to identify these determinants. BS suggest two covariates: a climate variable and a population density variable, both representing amenities of relevance to the potential migrant. The second reason is related to an interesting observation made by Friedberg and Hunt (1995). They suggest that if migration adds to convergence, we should expect it to act as an equilibrating mechanism reducing regional labour market imbalances. Hence, there should be 
a positive association between the tightness of the regional labour market and net or gross inmigration, and a negative association between tightness and gross out-migration. If migration detracts from convergence, we should expect exactly the opposite results. Estimating migration equations can, therefore, provide a simple consistency check on the results obtained from estimating the effect of migration on convergence, apart from being of interest in itself.

\begin{abstract}
Migration is closely related to the way in which labour markets work, for example in a neoclassical fashion with wages or income as key determinants, or in accordance to job search/job matching approaches where migration is seen as a special case of successful matching between vacancies and job searchers (see e.g. Jackman and Savouri, 1992). Both Norway and Sweden share a number of labour market characteristics that lead to wage compression (strong trade unions, centralized wage bargaining, many public employees,
\end{abstract} highly progressive income tax systems and means tested transfers). Accordingly, household earnings are predominantly determined by variations in employment and not by variations in hourly wages. However, we cannot completely dismiss the wage level as an explanatory variable for migration. We will, therefore, add output per capita as a proxy for the wage level to the set of covariates in the migration equations. ${ }^{6}$

We also expect that the effects of general regional labour market conditions on migration will depend on the region's industry composition. People working in different sectors may not have the same opportunities to find work elsewhere as human capital is, to a certain extent, sector specific (farmers are a good example). A county with a large primary sector may not have the same level of gross migration as a county where services are more important (although net migration levels may be the same - an example on how data on gross migration can convey information that net migration cannot). Another potentially important 
conditioning factor is the level of human capital, proxied by educational attainment. There is solid empirical evidence that migrants possess above average human capital (See Greenwood, 1997, and Shields and Shields, 1989). ${ }^{7}$ One reason for this might be that employment prospects depend on education. Generally, highly educated individuals face thin regional labour markets, which provide strong incentives for geographical mobility. We would, therefore, expect that a county rich in human capital would have high out-migration, ceteris paribus. We would also expect the county to have a high level of in-migration, as above average human capital endowment suggests that the region probably has an above average share of highly skilled jobs. Summarizing this discussion, we suggest the following migration equation

$m_{i, t}=f\left(y_{i, t-1}, x_{1, i, t-1}, x_{2, i, t-1}, x_{3, i, t-1}, z_{1, i}, z_{2, i}\right.$, year $\left._{t}\right)$

where $m$ is a generic symbol for $n m$, im or $o m, x_{2}$ is a variable reflecting regional labour market tightness, and $x_{3}$ represents the industrial structure, $z_{1}$ is a climate variable, and $z_{2}$ represents the population density. The $z$ variables are assumed to be sufficiently slow changing so that we may apply the slaving principle, i.e. they are treated as time invariant. As in the growth equation, we allow for period specific effects by introducing time dummies. The variable description is summarized in Table 2.1. Operational definitions are explained in more detail in Section 3.

[ TABLE 2.1 HERE]

\section{Data}


The spatial units of analysis are counties which correspond well to European NUTS3 regions. The county divisions of Norway and Sweden date back to the $17^{\text {th }}$ century, and the present divisions had, to a large extent, been established by the end of the $19^{\text {th }}$ century. ${ }^{8}$

An interesting feature in relation to Norway and Sweden is the lack of formal barriers to migration between the countries. This has been in effect since 1954 when a common labour market was established for the Nordic countries. The migratory flows between the two countries are, however, relatively modest. For the year 2000, emigration from Norway to Sweden was about 6500 individuals and immigration from Sweden to Norway was slightly less than 5000. In contrast, internal migration is much greater. The total number of migrants between the Norwegian counties was 155596 and between the Swedish counties 247903 in the same year. Our data does not, however, distinguish between in-migrants from other counties and those from foreign countries. The total numbers of in-migrants and out-migrants do not, therefore, sum to zero as is clearly seen from the first row of Table 3.1, showing migration rates for Norwegian and Swedish counties.

\section{[TABLE 3.1 HERE ]}

The dependent variable in the growth equation is the real GDP per capita. The data for Norway on the spatial distribution for 1980, 1985 and 1990 are all from a databank from Statistics Norway documented in Sørensen (1994). According to Sørensen, more effort was put into ensuring acceptable quality in the cross sectional dimension than in consistency over time. Data for 1995 and 2000 was downloaded from the Statistics Norway web site. The 1995 figures have, however, been subjected to a first revision of the national accounts according to the NACE standard and the 2000 figures have been subjected to yet a further revision. ${ }^{9}$ 
According to this latest revision, the 2000 regional figures are now consistent with the national figures. Whilst Statistics Norway has revised the national accounts for previous years in accordance with the latest revision, it has not done so with the regional figures. Comparing the aggregate for all the counties based on the regional data with the national figures there is no notable difference between them for 2000 (as would be expected) and for 1995 (more surprising). For previous years, the revised national figures are, however, larger than indicated by the regional data. The Swedish data on regional GDP pertain to two different series, one covering the period 1985 to 1996, and one revised series starting from 1993 (Statistics Sweden, 2001). The spatial distribution for all years, apart from 2000, is based on the older series. In order to improve comparability over time, we have imposed the restriction that the regional data add up to the revised national figure for each of the years we consider. In other words, we use the spatial distribution given by the regional data and the distribution of the aggregate over time according to the national data for Norway and Sweden, respectively. The nominal figures have been deflated by the national GDP deflators (for mainland production for Norway). Some summary statistics are given in the Table $3.2 \mathrm{a}$ and $\mathrm{b}$ below.

\section{[ TABLE 3.2 a AND b HERE ]}

Turning first to Norway, we observe that Oslo (the capital) has the largest GDP per capita for all years studied, more than twice the average. Data for other countries often show the same sort of pattern, with the capital area at the top of the distribution. However, what is somewhat surprising in the Norwegian case is the width of the difference. The Scandinavian countries are often perceived as egalitarian, but this does not show up in the regional GDP per capita distribution at the county level for Norway. If we compare with the distribution for counties in Great Britain presented in Roberts (2004), it appears that regional inequalities are much larger 
in Norway than in Great Britain. ${ }^{10}$ For 1979 , the coefficient of variation for GB was 11.8 per cent, for 1984 it was 14.2 per cent and, for 1989, 14.5 per cent. For Norway, the corresponding figures (with one year lead) were 26.8, 29.4 and $36.7 .^{11}$ In a qualitative sense, the two series tell the same story. The 1980s were years of increasing dispersion, or sigma divergence. For GB this appears to have continued into the 90 s with a figure of 17.1 percent for 1993, the latest figure reported by Roberts. On the other hand, the coefficient dropped to 26.1 per cent for Norway in 1995 . Hence, the early 90 s show some sigma convergence in the Norwegian case. If we look at all regular time periods possible within the 20 years time span shown in Table 3.2 a, we have eight different time periods (one covering 20 years, three encompassing 10 years, and four 5 year intervals). Only three of these indicate convergence in the sense of sigma.

The Swedish data also show the highest GDP per capita for the capital region, the region of Stockholm (Table $3.2 \mathrm{~b}$ ). The coefficients of variation (of GDP across regions) seem to be relatively close to those for Britain quoted above, and not in the same ball park as corresponding figures for Norway. Also, the relative gap between the richest and the poorest region is much wider in Norway than in Sweden. If we look at all regular time periods possible within the 15 years time span in Table $3.2 \mathrm{~b}$, we have six different time periods (one of 15 years, two of 10 years, and three of 5 years). Only one indicates convergence in the sense of sigma (1990-1995).

The migration data also reveal a persistent pattern over time as can be seen from Table $3.3 \mathrm{a}$ and b. In the case of Norway, Oslo and Akershus are in the top of the distribution for both inand out-migration. Akershus is Oslo's closest neighbour, hosting many commuters (which explains some of the high GDP per capita figures for Oslo). Counties on the west coast 
consistently appear at the other end of the distribution. This confirms popular beliefs, as expressed in this one-liner from a city on the west coast: You will not find a job here until someone else passes away! Notice that data on net migration alone would not be informative in this respect. The persistence is also clearly present in the Swedish data, although the regional differences in interregional migration rates is relatively lower than in Norway. The dynamic Uppsala region has the highest migration rates, and these are only partially explained by the mobility of university students. ${ }^{12}$

\section{[ TABLE 3.3 a and b HERE ]}

We follow the conventional dynamic panel setup and use real GDP per capita as the dependent variable. However, since most growth studies use the annual average growth rate as the dependent variable, we present some spatial properties of the growth rate along with the migration rates. Spatial dependence in the dependent variables could make the error terms in a stochastic spatial model correlated, if the covariates fail to account for the dependence. This would invalidate inference. In order to make a simple assessment of spatial dependence, we assume that counties only interact with their geographical neighbors. The neighbor adjacency binary weight matrix, representing the interaction has been row standardized so that all the elements representing neighbors add up to one. ${ }^{13}$ We notice from Table 3.4 that, judged by Moran's I tests, there is not much sign of spatial autocorrelation in the data (the hypotheses of no spatial autocorrelation is rejected at the 5 percent level for in-migration in the last period for Norway and for the growth rate in the last period for Sweden). ${ }^{14}$ This may come as a surprise. Income data for Swedish counties appear to be spatially correlated (Gustavsson and Persson, 2001), and so are the data of the European NUTS2 level (Badinger et al., 2004) and the data for British counties (Roberts, 2004). The test used is, as usual, an asymptotic 
approximation. With small samples, as is the case here, the power could be called into question, but Monte Carlo simulations suggest that in most cases the test is quite satisfactory (Anselin and Kelejian, 1997).

\section{[ TABLE 3.4 HERE ]}

Let us briefly describe the other variables. Human capital endowment is made operational by using educational attainment in the region. As a short hand, we will refer to the variable as "college". It measures the proportion of people with a college degree at the beginning of the time period. ${ }^{15}$

Unemployment rates are often used as the only or the main indicator of regional labourmarket imbalances or tightness in empirical work on migration (Westerlund, 1997). Regions with high rates of unemployment are expected to show higher rates of out-migration than regions with lower unemployment. However, measuring regional unemployment adequately can be problematic. Both Norway and Sweden allocate substantial resources to active labour market policy programs. This means that the official regional unemployment rate may not be a good indicator of labour market tightness because participants in programs are not registered as unemployed. Moreover, labour force participation varies pro-cyclically and the officially registered "open" unemployment does not include "latent" unemployment, i.e., unemployed individuals who start to search for a job and enter the labour force when employment probabilities increase. This suggests that the employment to population rate at the beginning of the period is a better measure of labour market tightness than the unemployment rate. ${ }^{16}$ In the analysis, we use the ratio of employed to the working age population (the population 2064 years of age) in the region as the indicator of employment possibilities. 
To control for differences in industry structure, we have considered a variable similar to the one used by BS to capture differences in short term fluctuations caused by different industry mixes across counties. We used the weighted sum of labour productivity growth for the whole country in the primary, secondary and tertiary sectors of production, measured by the rate of change in real value added per worker (BS use a somewhat finer classification). The weights are the shares of the aggregated value added for each sector in the county (BS use employment). However, the BS index performed poorly in all the models we estimated and we have, therefore, preferred to employ the simpler and more intuitive primary share of value added, used by, e.g., Fagerberg et al (1997).

The climate variable used by BS was the normal heating degree days. We have used the same variable for Norway, based on observations for the period 1971-2000 (Aune, 2002). We were, however, not able to find the heating degree days for Sweden. Instead, we have used the number of frost nights. The operational definition of the second amenity variable, population density, also varies somewhat between the two countries. For Sweden, we have simply used population density within the county. For Norway, we have used the density for urban areas within the county.

\section{Estimation}

The kind of growth model that we estimate is often written in the following form,

$$
\Delta y_{i, t}=(\alpha-1) y_{i, t-\tau}+m_{i, t}{ }^{\prime} \beta+\gamma x_{1, i, t-\tau}+\mu_{t}+\eta_{i}+v_{i, t}
$$


where $\Delta y_{i, t}$ is the log difference in GDP per capita over the time period (approximately equal to the growth rate), $y_{i, t-1}$ is the log of GDP per capita at the beginning of the time period, $m_{i, t}$ is a vector of migration rates, and $x_{i, t-1}$ is the log of human capital. When data are available, the investment rate averaged over time and the population growth rate are often added to the regressors in order to proxy for the investment rate and population growth rate in steady state. In addition to these Solow variables suggested by theory, other variables suspected to condition the steady state may be included. Rather than specifying conditioning variables in operational terms, we follow Miller and Upadhyay (2002) and allow for differences in steady state as well as initial efficiency through the individual effects, $\eta_{i}$. Productivity changes, common to all regions are represented by the time dummy, $\mu_{t}$, and $v_{i, t}$ is a transient error term.

This is a dynamic panel so we may rewrite equation (4.1) equivalently in standard panel data form (4.2), so that it is clear that we indeed have a lagged dependent variable on the right side: ${ }^{17}$

$$
y_{i, t}=\alpha y_{i, t-\tau}+m_{i, t}{ }^{\prime} \beta+\gamma x_{1, i, t-\tau}+\mu_{t}+\eta_{i}+v_{i, t}
$$

With a lagged dependent variable among the regressors, we should consider not only instrumenting the migration rates, but also the lagged dependent variable.

Several recent convergence studies recommend the use of an instrumental variable approach based on the GMM system estimator proposed by Blundell and Bond (1998) when estimating dynamic panels with small samples (Bond et al., 2001, and Badinger et al., 2004). The properties of the estimator in the presence of endogenous covariates, properties that make it more appealing in applications, are discussed in Blundell et al. (2000). 
The lagged dependent variable and the migration rates in (4.2) are instrumented with suitable lags of their own first differences. In the GMM system approach, equation (4.2) in first differences is added to the levels equation, and the first differences of the lagged dependent variable and the migration rates are instrumented with lags of their own levels. Instrument validity is tested for by investigating serial correlation in the first-difference equation residuals. First order correlation is expected, but not higher order correlation. Since the model is overidentified (with more than 3 time series observations), validity of overidentifying restrictions are tested for by using the Sargan test or the Hansen J test.

In order to see how the migration rates influence the convergence rate estimate, we have first estimated the three versions of the growth equation reported in Table 4.1.

\section{[ TABLE 4.1 HERE ]}

The column to the right gives the results from the slimmest version, with only the initial GDP per capita as the explanatory variable except for time dummies. We observe that the parameter is hardly significantly different from 1 at the 5 percent level and that the implied interval estimate of the convergence rate does not, therefore, preclude divergence at a significance level marginally below the conventional level. ${ }^{18}$ Hence, there is rather weak evidence for beta-convergence between counties when we allow for different steady states through random effects. The middle column gives results for the case when the net-migration factor has been added to the explanatory variables. The suggested convergence rate goes down (point estimate). This is consistent with the quantity effect dominating the composition effect, and divergence seems more likely than in the previous case without migration. If we move to the left hand column, which reports the results when we use gross migration rates 
instead of the net migration factor as the explanatory variables, we observe a dramatic change between the two countries. Looking first at Norway (Table 4.1), we notice that the convergence rate estimate is substantially increased. We can be fairly confident that there is convergence, once we control for different gross migration flows. The result is consistent with migration flows where people moving into a county possessing on average more human capital than the people already residing in the host county. This means that the composition effect dominates the quantity effect. We also observe that there is no support for the idea that in- and out-migration work symmetrically. In fact, imposing the symmetry restriction, as is done de facto by employing the net-migration factor as a regressor instead of gross-migration rates, leads to opposite and contradictory results. Next, looking at the results for Sweden in Table 4.1, we notice that the point estimate for the convergence rate goes down in the gross migration specification in comparison with the two alternative specifications. This is in accordance with the quantity effect dominating over the composition effect. We also observe that there is not much difference between the net and the gross version - both basically suggest a zero convergence rate and, contrary to the Norwegian case, in-migration and outmigration appear to work fairly symmetrically. ${ }^{19}$

As judged by the Moran-statistic for the residuals in levels (Cliff and Ord, 1972), there is no indication of autocorrelation for either Norway or Sweden when we use a conventional standardized binary weight matrix based on contiguity and the results seem to be reasonably robust to the choice of weighting matrix. ${ }^{20}$ The other test-statistics also indicate that the models appear to work reasonably well. We report test-statistics that are robust with regard to heteroscedasticity and autocorrelation (based on the two-step GMM criterion function) as well as non-robust statistics. The reason for this is that the robust tests appear to have lower power than the non-robust tests. The non-robust tests seem to accept the null hypothesis, that the 
instruments are not valid, all too often, whereas the robust tests seem to reject the null too frequently.

Next, we re-estimated the model with the college variable added. The results are reported in Table 4.2, and we start with commenting the results for Norway.

\section{[ TABLE 4.2 HERE ]}

When we control for education, keeping the net migration fixed no longer reduces the rate of convergence. This is consistent with a dominating quantity effect similar to an increase in population. Now, the rate of convergence is increasing just as it does when we keep in- and out-migration rates fixed, which is consistent with a dominant composition effect. Once we control for education, the gross and net versions give about the same convergence rate, and we see why from the first column in Table 4.2. When we keep education fixed, the migration effects appear to be close to symmetric. Judging by the signs, the effect of in-migration is negative while that of out-migration is positive, which is in accordance with neoclassical theory. However, the standard errors are too large to make any definite statements. The importance of this is the following: when a neoclassical model is extended by including migration and human capital, we estimate the effect of migration on convergence between counties that are similar with respect to educational attainment. It turns out that the effect is quite small and poorly identified. As the effect was large and significant when we did not hold educational attainment constant, the major part of the impact must be attributed to migration between counties that are different in terms of the human capital endowments they possess. 
For Sweden, the effect of net-migration on convergence still suggests a dominating quantity effect. The effect of gross-migration appears to vanish as it did for Norway. The implications are, therefore, that also in Sweden the major effect of migration on convergence works through migration between counties with different levels of human capital. However, in this case the results are consistent with a shift in human capital in favour of the lagging regions and not the leading regions as is the case for Norway.

We have emphasized the effects of migration on the rate of convergence. However, what about the effects of migration on the dependent variable? Apart from in the last specification for Sweden, there appears to be virtually no measurable effect. A reasonable interpretation of this is that the interaction between migration and growth is largely a short term phenomenon. Migration affects growth through the transitory dynamics towards the steady state and does not influence long term growth or the steady-state.

\section{[ TABLE 4.3 HERE ]}

Let us now turn to the migration equation suggested by equation 2.3. Adding stochastic error terms, we have estimated net and gross migration equations by using simple OLS on pooled data. We argued in Section 2 that imbalances could be particularly important for migration in countries with a compressed wage structure, such as Norway and Sweden. We also paid attention to the observation by Friedberg and Hunt (1995), that the effects of migration on convergence have implications for the expected signs on the labour market tightness variable in migration equations. From what we have learned about the effect of migration on convergence in Norway and Sweden, we would predict a negative sign on the labour market tightness variable in the net and in-migration equations for Norway and a positive sign for 
Sweden. This is, indeed, confirmed by the data as can be seen from the results in Table 4.3.

We would also expect opposite signs on the labour market tightness variable in the gross out migration equation, but here the estimates are less well identified (and with an unexpected sign for Sweden).

The effect of GDP per capita enters with the expected signs for Norway, but is only statistically significant in the net-migration equation. For Sweden, it is significant in the gross equations but not in the net equation. It enters with expected sign only in the out-migration equation. The college variable enters with a positive and statistically significant effect in all the specifications in both samples, and the effect is large in all the gross equations. The effect of the primary share variable appears to be very small and not well identified except in the net equation for Norway where it enters with a negative sign. Population density enters significantly in the out and net equations across samples. However, from the signs it appears that density represent an amenity in Sweden and a disamenity in Norway, but this difference could be due to the different definitions of the density variable used (in Norway it is density in urban areas, whereas in Sweden it is the overall density in the county). The climate variable that appeared with the expected sign in the net equations (although not well identified in the case of Sweden), continues to do so in the gross out-migration equation for Norway.

However, the sign is contrary to expectations for the in-equation. For Sweden, the effects are not well identified and the sign is contrary to expectations for the gross out equation. Overall, the results suggest that the one-dimensional climate indicator suggested by BS, is probably too simplistic to perform well across samples (there may not be many heating degree days in Bergen, but it most certainly can rain). 
We observe that there does not seem to be any spatial autocorrelation in the residuals for either of the samples nor in any of the specifications, as judged by Moran's I tests at the 5 per cent level. If we were to adjust the level of significance from 5 to 10 per cent, there are some indications of spatial dependence in the net residuals (the last period for Norway and the first period for Sweden), but not in the gross residuals.

\section{Discussion}

Is migration important for regional convergence? When we regress output per capita on the lagged dependent variable, the implied rate of growth convergence is estimated to be 3.9 percent for Norway (see Table 4.1). However, it is hardly significant at the 5 percent level and we cannot with confidence rule out divergence. Introducing net migration in the regression does not change this qualitatively, whereas including gross migration does. Conditioning on gross migration rates, the convergence rate estimate is increased to 8.7 percent with a likely interval from 1.4 to 22 percent. These results have two very interesting implications. Firstly, in- and out-migration does not work symmetrically in the growth equation. Hence, net migration cannot in general be used as a reduced form for gross migration. Secondly, inmigration (out-migration) does not have a negative (positive) impact on output per capita, as would be expected in a neoclassical growth model with homogeneous labour.

When we extend the model, by controlling for the level of human capital, the convergence rate still goes up when we keep migration constant. However, it only does so by one tenth of a percentage point, as judged by the point estimates, and the likely intervals for the estimates are clearly overlapping. It appears, therefore, that the strong effect of gross migration on 
convergence is due to migration between counties with different endowments of human capital, rather than between similar counties. These results are consistent with a very strong positive effect on the output per capita in the destination region of the human capital brought there by the in-migrants, and/or a negative effect on per capita output of the human capital exiting the region. In other words, what has been called the composition effect clearly outweighs the quantity effect.

For Sweden, the data suggests the opposite result. When migration is allowed to affect the convergence rate, the point estimate suggests a rate of 2.8 per cent. When migration is kept constant, the rate drops to close to zero. Hence, migration appears to add to convergence, which is consistent with a dominance of the quantity effect.

This is also true when we control for human capital. However, the change in the convergence rate estimates when we include gross migration, is much smaller. Hence, it appears that, also in the Swedish case, the migration between counties with different human capital endowments is more important for convergence than the mobility between similar counties. Nevertheless, there is an important difference. In the case of Norway, we had a situation consistent with what is often called brain-drain (when seen from the periphery). In Sweden on the other hand, the situation is consistent with brain-gain.

Friedberg and Hunt (1995) observe that, if we have a situation similar to the one that we have described for Norway, we should not expect migration to assist in correcting for regional labour market imbalances. For the U.S. states, BS find some evidence indicating that migration detracts from convergence which corresponds to our findings for Norwegian counties. On the other hand, Blanchard and Katz (1992) find that migration correct labour 
market imbalances, and Friedberg and Hunt refer to this contradiction as the puzzle of U.S. internal migration. It is interesting to note that this puzzle does not arise in our samples. In Norway, more people tend to move out of than into counties with a tight labour market as measured by employment per working capita. Hence, as we would expect, migration adds to the regional labour market imbalances. In Sweden, in keeping with Friedberg and Hunt's conjecture, we would expect the opposite situation, and this is, indeed, what we find. Migration appears to be a stabilizing factor, reducing imbalances. Previous research based on Swedish data, confirms that interregional migration in Sweden acts as an equilibrating mechanism when regions experience temporary regional disequilibria (Fredriksson, 1999 and Westerlund 1997). ${ }^{21}$ Are our results influenced by the presence of spatial autocorrelation, which is found to be a problem in many other regional datasets? Judging from the Moran tests that we have performed on residuals for every model we have estimated, the answer would appear to be no.

Summarizing, we may say that internal migration during the last few decades in Norway seems to have been a centripetal force working against regional conditional convergence, whereas in Sweden, migration seems to have acted as a centrifugal force working in the opposite direction. An interesting question that immediately comes to mind is whether Sweden and Norway really are so different? It could perhaps be that the Swedish and the Norwegian cases describe two different sequences of the same developing process, with Sweden some years ahead. The answer to this could be an issue for future research when longer data series have become available as history unfolds. 


\section{REFERENCES}

Anselin L. and Kelejian H. H. (1997) Testing for spatial error autocorrelation in the presence of endogeneous regressors, International Regional Science Review 20, 153-182.

Aronsson T., Lundberg J. and Wikström M. (2001) Regional Income Growth and Net Migration in Sweden 1970-1995, Regional Studies 35 (9), 823-830.

Aune B. (2002) Energi gradtall (Heating degree days). Normaler 1961-1990. Normaler 19712000, Rapport Klima 23, Norwegian Meteorological Institute, Oslo.

Badinger H., Müller W. G. and Tondl G. (2004) Regional convergence in the European Union, 1985-1999: a spatial dynamic panel analysis, Regional Studies 38 (3), 241-53.

Barro R. and Sala-i-Martin X. (2004) Economic Growth, $2^{\text {nd }}$ ed. The MIT-Press, Cambridge Mass,

Bavaud F. (1998) Models for spatial weights: a systematic look. Geographical Analysis 30, 153-71.

Blanchard O. and Katz L. (1992) Regional evolutions. Brookings Papers on Economic Activity 1, 1-61.

Blundell R. and Bond S. (1998) Initial conditions and moment restrictions in dynamic panel data models, Econometrica 87 (1), 115-43. 
Blundell R., Bond S. and Windmeijer F. (2000) Estimation in dynamic panel data models: improving on the performance of the standard GMM estimator, in Baltagi, B. H. (ed), Nonstationary Panels, Panel Cointegration, and Dynamic Panels. Advances in Econometrics vol. 15, Elsevier, Amsterdam, 53-91.

Bond S., Hoeffler A. and Temple J. (2001) GMM estimation of empirical growth models, CEPR Discussion Paper No. 3048, Centre for Economic Policy Research, London.

Cahuc P. and Zylberberg A. (2004) Labour Economics. The MIT-Press, Cambridge Mass.

Cliff A. and Ord J. K. (1972) Testing for spatial autocorrelation among regression residuals, Geographical Analysis 4, 267-284.

Dalgaard C. J. and Vastrup J. (2001) On the measurement of $\sigma$-convergence, Economics Letters 70, 283-87.

Dolado J., Goria A. and Ichino A. (1993) Immigration, human capital and growth in the host country, Journal of Population Economics 7 (2), 193-215.

Edvardsen H. M. (2004) Regional policy in Sweden and Norway, NIBR Report 2004:13, Oslo.

Fagerberg J., Verspagen B. and Caniëls M. (1997) Technology, growth and unemployment across European regions, Regional Studies 31, 457-466. 
Fujita M., Krugman P. and Venables A. J. (1999) The Spatial Economy. MIT-Press, Cambridge Mass.

Greenwood M. J. (1997) Internal migration in developed countries, in Handbook of Population and Family Economics, Rosenweig, M. R. and Stark O. (editors), Elsevier, Amsterdam, 647-711.

Gustavsson P. and Persson J. (2001) Convergence, prices and geography: An empirical study of the Swedish counties 1911-1993, in Gustavsson, P., Essays on Trade, Growth and Applied Econometrics, PhD dissertation, Stockholm School of Economics, Stockholm.

Jackman R. and Savouri S. (1992) Regional Migration in Britain: An Analysis of Gross Flows using NHS Central Register Data”, Economic Journal, 102,1433-1450.

Miller, S. M. and Upadhyay, M. P. (2002) Total factor productivity and the convergence hypothesis, Journal of Macroeconomics 24: 267-286. 
Østbye S. (2004) The translog neoclassical growth model. Working Paper 02/04, Dept of Economics, University of Troms $\varnothing$, Troms $\varnothing$.

Ottaviano G. I. P. and Thisse J-F. (2002) Integration, agglomeration and the political economics of factor mobility, Journal of Public Economics 83, 429-56.

Roberts M. (2004) The growth performance of the GB counties: some new empirical evidence for 1977-1993. Regional Studies 38 (2), 149-65.

Shields G. M. and Shields M. P. (1989) The emergence of migration theory and a suggested new direction. Journal of Economic Surveys 3, 277-304.

Shioji E. (2001) Composition effect of migration and regional growth in Japan, Journal of the Japanese and International Economies 15, 29-49.

Sjaastad L. A. (1962) The costs and returns to human migration, Journal of Public Economics 70, 80-93.

Sørensen K. Ø. (1994) En databank med fylkesfordelte nasjonalregnskapstall. Statistics Norway Notater 94/12, Oslo.

Staiger, D. and Stock J. H. (1997) Instrumental variables regression with weak instruments, Econometrica 65: 557-586. 
Statistics Sweden (2001) Regionala räkenskaper 1993-2001, Statistiska meddelanden 13, SM 0401 .

Westerlund O. (1997) Employment opportunities, wages and interregional migration in Sweden 1970-1989. Journal of Regional Science 37, 55-73.

Wössmann L. (2003) Specifying human capital. Journal of Economic Surveys 17, 239-269.

\begin{abstract}
Acknowledgements - This research has been undertaken with the support of the Swedish Institute for Growth Policy Studies (ITPS). The authors acknowledge helpful comments and valuable suggestions from Kent Eliasson at ITPS, Robert A. Nakosteen, University of Massachusetts at Amherst, and two anonymous referees. Suggestions on an early draft presented at the WRSA meeting in San Diego in 2005 are also appreciated.
\end{abstract}

\footnotetext{
NoTES

${ }^{1}$ See, e.g., Fujita et al (1999), p. 240.

${ }^{2}$ Although we refer to the neoclassical interpretation here, we should be aware that another story could be told where technology differences replace the mechanism of diminishing returns as an explanation for growth differences. However, from an empirical point of view, it is difficult to discriminate between these hypotheses that are probably best regarded as complementary. Fagerberg et al. (1997) provide a good example of the technology-gap approach to regional economic growth where migration is included.

${ }^{3}$ This problem inherent in estimating net migration functions has been recognized for a long time, see e.g., Sjaastad 1962.
} 
${ }^{4}$ Economic geography models based on increasing returns often predict the opposite.

${ }^{5}$ The relationship depends on what functional form is specified for the aggregate production technology. Almost without exception, Cobb-Douglas technology is implicitly assumed, but the relationship is easily deduced from less restrictive functional forms, e.g., translog (see Østbye, 2004). With Cobb-Douglas the rate of convergence is computed as $-1 / 5 \ln \hat{\alpha}$ when the period between observations is 5 years and the point estimate on the lagged dependent variable is $\hat{\alpha}$.

${ }^{6}$ With minor exceptions, migration flows in Sweden have for a long time generally been directed from rural to urban areas and metropolitan areas, from economically depressed regions to relatively prosperous regions, and from the inland to the coastal regions. A similar pattern is observed for Norway, although the change in the spatial distribution of the population has emerged at a slower pace than in Sweden. Previous studies on migration in Sweden indicate that internal migration responds as expected to regional differences in employment opportunities (See e.g. Westerlund 1997 and Fredriksson 1999).

${ }^{7}$ This has been used as argument in new economic geography models, to assume that lowskilled labour is immobile, whereas high-skilled is mobile (see Ottaviano and Thisse, 2002).

${ }^{8}$ Sweden had 23 counties in 1634 , and already by 1810 the number was 24 which is identical to the number of counties in our Swedish sample. Norway under Danish rule was divided into 12 counties in the 1660 s. In 1866 the number had increased to 20 - reduced to our sample of 19 in 1972 when Bergen lost county status (Edvardsen, 2004).

${ }^{9} \mathrm{NACE}$ is an acronym for "Nomenclature générale des Activités economiques dans les Communautés Européens”, the European standard for industry classification. 
${ }^{10}$ Although counties are the statistical units in both studies, observe that county size in terms of population varies considerably between countries. The difference between Britain and Norway could, therefore, in part be due to different levels of aggregation

${ }^{11}$ If we exclude Oslo, the series read 12.1, 13.5, 10.5, 9.4 and 10.0. Hence, Oslo is very important and drives the result from 1985 to 1990 . On the other hand, London is presumably as important in the GB sample. However, we do not know from the article by Roberts what the numbers would have looked like if London had been excluded.

${ }^{12}$ The flow of students would not amount to more than about a quarter of a percentage unit of the total in-migration rate for Uppsala if every freshman were recruited from other counties.

${ }^{13}$ Properties of weight matrices are discussed in Bavaud (1998).

${ }^{14}$ We also used distance based weight matrices to see how sensitive results were to the choice of matrix. Distance is travelling distance by road between the most important municipalities (in terms of population) of the counties. Using inverse distance as entries in a standardized matrix did not make any difference for Sweden. For Norway no spatial autocorrelation could now be rejected at the 5 per cent level for the growth rate 1990-1995. Using inverse squared distance as entries, results remained unchanged for Sweden except for out-migration 1995-2000. For Norway there were sign of autocorrelation for both migration rates in the last period, but not in the growth rate for any period. We did also tested for spatial autocorrelation in the levels of per capita GDP since levels are often used as dependent variable in panel data setups. Again we tried the two distance based weight matrices in addition to the binary contiguity matrix. For Norway there were no sign of spatial autocorrelation. For Sweden we could reject the hypothesis of no autocorrelation for 2000 when we used the inverse squared distances. 
${ }^{15}$ Wössmann (2003) surveys different operational definitions of human capital that has been used in the empirical literature.

${ }^{16}$ Another possible indicator of labour market tightness is the ratio of unemployed to vacancies (see, e.g., Cahuc and Zylberberg, 2004, p.521). We made some experiments using this variable as well and found that, for the Norwegian sample, it worked about the same way as the one we have proposed. However, as we did not have this indicator available for Sweden, we decided to stick to our own indicator.

${ }^{17}$ The most common practice in growth models is to use the annual average growth rate as the dependent variable, as in BS. ALW use the growth rate. However, both the BS and the ALW specifications could be transformed to a specification similar to ours with the current level as the dependent variable (as used in, e.g. Badinger et al., 2004).

${ }^{18}$ The point estimate of the coefficient on the lagged dependent variable in the "No" version for Norway is between the Within-Group (-.027) and OLS (.958) estimates. For Sweden the interval provided by Within-Groups and OLS is $(-.482, .970)$. We expect the GMM system estimate to be inbetween since Within-Groups is known to be downward biased and OLS upward biased. The GMM system estimates appear all to be well within this interval.

${ }^{19}$ Following a suggestion by a referee, we also tried an alternative specification with interaction variables involving migration rates and the lagged dependent variable instead of simple migration rates. As the effect on the convergence rate turned out to be almost insensitive to this respecification, we have chosen to report the results from the BS approach.

${ }^{20}$ Besides the standardized binary matrix based on contiguity, we tried the standardized matrix based on inverse squared distance. We did not find indication of spatial autocorrelation 


\begin{abstract}
for Sweden. For Norway, we could reject the hypothesis of no spatial autocorrelation at the 5 per cent level in two instances when we used the distance based matrix: the "No" version 1980-1985 and the "Gross" version 1990-1995.

${ }^{21}$ Research on internal migration in Norway has mostly been based on microeconomic data. The few contributions on the level of aggregation that is interesting for direct comparison tend to be rather dated, using data for the 1970's. The results from that period seem to be opposite of what we have found for more recent years. It is difficult to have any opinion on whether this is due to the sample period or to differences in methodology and definitions.
\end{abstract}




\section{TABLES}

\section{TABLE 2.1 VARIABLE DESCRIPTION}

$y_{i, t}: \quad$ Real GDP per capita in year $t$.

$i m_{i, t}$ : The in-migration rate defined as the number of persons migrating into the county between the start of the period, $t-1$, and $t$, divided by the population of the county in $t-1$. $\mathrm{om}_{i, t}$ : The out-migration rate is defined analogously to the in-migration rate.

$n m_{i, t}:$ The net-migration factor defined as $(1+$ the net migration rate) where the net migration rate is defined analogously to the gross migration rates.

$x_{1, i, t-1}$ : Share of population with college education in year $t-1$.

$x_{2, i, t-1}:$ Employment/working age population in year $t-1$.

$x_{3, i, t-1}:$ Share of regional value added from primary production in year $t-1$.

$z_{4, i}$ : Climate, Norway: The normal heating degree days for the period 1970-2000, Sweden: Average number of frost days for 2001 and 2002.

$z_{5, i}$ : Population density 2000, Norway: Population density in urban areas within the county, Sweden: Population density in the county. 
Table 3.1 Average annual interregional migration in Norway and Sweden 1980-2000, percent of population in 1980.

\begin{tabular}{|c|c|c|c|c|c|c|c|}
\hline \multicolumn{4}{|l|}{ Norwegian counties } & \multicolumn{3}{|l|}{ Swedish counties } & \multirow[b]{2}{*}{ Net } \\
\hline & In & Out & Net & & In & Out & \\
\hline Norway & 3.22 & 3.03 & .20 & Sweden & 2.56 & 2.35 & .21 \\
\hline$\varnothing$ Østfold & 2.42 & 2.05 & .37 & Stockholm & 2.58 & 2.20 & .38 \\
\hline Akershus & 5.60 & 4.85 & .75 & Uppsala & 4.69 & 3.66 & 1.03 \\
\hline Oslo & 5.88 & 5.43 & .45 & Södermanland & 2.93 & 2.89 & .04 \\
\hline Hedmark & 2.46 & 2.26 & .20 & Östergötland & 2.21 & 2.04 & .17 \\
\hline Oppland & 2.66 & 2.49 & .17 & Jönköping & 2.41 & 2.38 & .03 \\
\hline Buskerud & 3.39 & 2.93 & .46 & Kronoberg & 2.75 & 2.63 & .12 \\
\hline Vestfold & 3.11 & 2.47 & .64 & Kalmar & 2.22 & 2.18 & .04 \\
\hline Telemark & 2.22 & 2.10 & .12 & Gotland & 2.49 & 2.12 & .37 \\
\hline Aust-Agder & 3.24 & 2.77 & .47 & Blekinge & 2.09 & 2.16 & -.07 \\
\hline Vest-Agder & 2.88 & 2.59 & .29 & Kristianstad & 2.61 & 2.44 & .17 \\
\hline Rogaland & 2.72 & 2.42 & .30 & Malmöhus & 2.34 & 1.89 & .45 \\
\hline Hordaland & 2.10 & 2.03 & .07 & Halland & 3.81 & 2.42 & 1.39 \\
\hline Sogn og Fjordane & 2.25 & 2.45 & -.20 & Göteborgs och Bohus & 2.93 & 2.74 & .19 \\
\hline Møre og Romsdal & 1.90 & 2.05 & -.15 & Älvsborg & 2.88 & 2.55 & .33 \\
\hline Sør-Trøndelag & 2.67 & 2.60 & .07 & Skaraborg & 2.23 & 2.02 & .21 \\
\hline Nord-Trøndelag & 2.30 & 2.50 & -.20 & Värmland & 2.08 & 1.99 & .09 \\
\hline Nordland & 2.26 & 2.63 & -.38 & Örebro & 2.36 & 2.27 & .09 \\
\hline Troms & 3.23 & 3.55 & -.32 & Västmanland & 2.59 & 2.70 & -.11 \\
\hline \multirow[t]{6}{*}{ Finnmark } & 3.73 & 4.60 & -.87 & Kopparberg & 2.22 & 2.14 & .08 \\
\hline & & & & Gävleborg & 2.05 & 2.03 & .02 \\
\hline & & & & Västernorrland & 1.94 & 2.05 & -.11 \\
\hline & & & & Jämtland & 2.71 & 2.51 & .20 \\
\hline & & & & Västerbotten & 2.38 & 2.21 & .17 \\
\hline & & & & Norrbotten & 1.85 & 2.10 & -.25 \\
\hline
\end{tabular}


Table 3.2 a Descriptive statistics GDP per capita, counties in Norway

\begin{tabular}{|c|c|c|c|c|c|}
\hline & 1980 & 1985 & 1990 & 1995 & 2000 \\
\hline Mean & 140815 & 168255 & 161262 & 194141 & 222268 \\
\hline \multirow{2}{*}{ Maximum } & 282329 & 354025 & 397646 & 391720 & 506053 \\
\hline & Oslo & Oslo & Oslo & Oslo & Oslo \\
\hline \multirow[t]{2}{*}{ Minimum } & 111748 & 132112 & 123854 & 156935 & 178639 \\
\hline & $\begin{array}{l}\text { Nord- } \\
\text { Trøndelag }\end{array}$ & Oppland & Oppland & Oppland & Oppland \\
\hline Standard deviation & .2095 & .2229 & .2502 & .1971 & .2274 \\
\hline of $\log s$ & $(.1195)$ & (.1249) & $(.1065)$ & $(.0926)$ & (.0977) \\
\hline $\begin{array}{l}\text { Coefficient of } \\
\text { variation }\end{array}$ & $26.8(12.1)$ & $29.4(13.5)$ & $36.7(10.5)$ & $26.1(9.4)$ & $32.2(10.0)$ \\
\hline
\end{tabular}

Note: Nominal values are deflated by the national GDP deflator for mainland production. For all years, the means have been restricted to take the same value as the mean for mainland GDP based on national figures that have been revised according to latest revision. We have two scale free measures of sigma convergence, the standard deviation of logs and the coefficient of variation, since Dalgaard and Vastrup (2001) have shown that the two measures may give opposite conclusions depending on the sample. Oslo is driving the result from 1985 to 1990 (measures excluding Oslo in parenthesis).

Table 3.2 b Descriptive statistics GDP per capita, counties in Sweden

\begin{tabular}{|c|c|c|c|c|c|}
\hline & 1980 & 1985 & 1990 & 1995 & 2000 \\
\hline Mean & $\mathrm{n} \mathrm{a}$ & 173435 & 197094 & 200146 & 222038 \\
\hline \multirow[t]{2}{*}{ Maximum } & $\mathrm{n} \mathrm{a}$ & 210252 & 274328 & 260508 & 342620 \\
\hline & & Stockholm & Stockholm & Stockholm & Stockholm \\
\hline \multirow[t]{2}{*}{ Minimum } & $\mathrm{n}$ a & 154960 & 163873 & 172139 & 194335 \\
\hline & & Älvsborg & Älvsborg & Älvsborg & Halland \\
\hline $\begin{array}{l}\text { Standard deviation } \\
\text { of logs }\end{array}$ & $\mathrm{n} \mathrm{a}$ & $\begin{array}{l}.0734 \\
(.0617)\end{array}$ & $\begin{array}{l}.1063 \\
(.0803)\end{array}$ & $\begin{array}{l}.0934 \\
(.0756)\end{array}$ & $\begin{array}{l}.1254 \\
(.0847)\end{array}$ \\
\hline $\begin{array}{l}\text { Coefficient of } \\
\text { variation }\end{array}$ & $\mathrm{n} \mathrm{a}$ & $7.6(6.3)$ & $11.5(8.3)$ & $9.7(7.6)$ & $14.3(8.8)$ \\
\hline
\end{tabular}

Note: Nominal values are deflated by the national GDP deflator. Stockholm is driving the result from 1995 to 2000 (measures excluding Stockholm in parenthesis). 
Table 3.3 a Descriptive statistics migration, counties in Norway

In-migration

\begin{tabular}{|c|c|c|c|c|c|}
\hline & $1975-1980$ & 1980-1985 & $1985-1990$ & 1990-1995 & $1995-2000$ \\
\hline Mean & 3.1 & 2.8 & 2.9 & 2.8 & 3.2 \\
\hline \multirow[t]{2}{*}{ Maximum } & 5.2 & 5.4 & 5.8 & 5.7 & 6.4 \\
\hline & Akershus & Akershus & Oslo & Oslo & Oslo \\
\hline \multirow{2}{*}{ Minimum } & 2.0 & 1.7 & 1.8 & 1.9 & 2.2 \\
\hline & $\begin{array}{l}\text { Møre-og- } \\
\text { Romsdal }\end{array}$ & $\begin{array}{l}\text { Møre-og- } \\
\text { Romsdal }\end{array}$ & $\begin{array}{l}\text { Møre-og- } \\
\text { Romsdal }\end{array}$ & $\begin{array}{l}\text { Møre-og- } \\
\text { Romsdal }\end{array}$ & $\begin{array}{l}\text { Møre-og- } \\
\text { Romsdal }\end{array}$ \\
\hline \multicolumn{6}{|c|}{ Out-migration } \\
\hline & $1975-1980$ & $1980-1985$ & $1985-1990$ & 1990-1995 & $1995-2000$ \\
\hline Mean & 2.9 & 2.7 & 2.9 & 2.7 & 3.0 \\
\hline \multirow{2}{*}{ Maximum } & 5.2 & 5.2 & 5.4 & 4.8 & 6.0 \\
\hline & Akershus & Oslo & Oslo & Oslo & Oslo \\
\hline \multirow[t]{2}{*}{ Minimum } & 2.1 & 1.9 & 2.0 & 1.9 & 2.1 \\
\hline & $\begin{array}{l}\text { Møre-og- } \\
\text { Romsdal }\end{array}$ & $\begin{array}{l}\text { Møre-og- } \\
\text { Romsdal }\end{array}$ & Hordaland & Hordaland & Hordaland \\
\hline
\end{tabular}

Table 3.3 b Descriptive statistics migration, counties in Sweden

In-migration

\begin{tabular}{lccccc}
\hline & $\mathbf{1 9 7 5 - 1 9 8 0}$ & $\mathbf{1 9 8 0 - 1 9 8 5}$ & $\mathbf{1 9 8 5 - 1 9 9 0}$ & $\mathbf{1 9 9 0 - 1 9 9 5}$ & $\mathbf{1 9 9 5 - 2 0 0 0}$ \\
\hline Mean & 2.6 & 2.1 & 2.6 & 2.7 & 2.5 \\
Maximum & 4.4 & 3.6 & 4.1 & 4.5 & 4.1 \\
& Uppsala & Uppsala & Uppsala & Uppsala & Uppsala \\
Minimum & 2.1 & 1.7 & 2.0 & 2.0 & 1.8 \\
& Värmland & Värmland & Norrbotten & Norrbotten & Norrbotten \\
\hline Out-migration & & & & & \\
\hline & $\mathbf{1 9 7 5 - 1 9 8 0}$ & $\mathbf{1 9 8 0 - 1 9 8 5}$ & $\mathbf{1 9 8 5 - 1 9 9 0}$ & $\mathbf{1 9 9 0 - 1 9 9 5}$ & $\mathbf{1 9 9 5 - 2 0 0 0}$ \\
\hline Mean & 2.4 & 2.1 & 2.3 & 2.5 & 2.6 \\
Maximum & 3.7 & 3.3 & 3.4 & 3.6 & 4.0 \\
& Uppsala & Uppsala & Uppsala & Uppsala & Uppsala \\
Minimum & 1.8 & 1.7 & 1.8 & 1.9 & 2.2 \\
& Värmland & Värmland & Malmöhus & Malmöhus & Malmöhus \\
\hline
\end{tabular}


Table 3.4 Spatial properties of dependent variables

Norway

\begin{tabular}{lccc}
\hline & Growth rate & Migration rate in & Migration rate out \\
\hline $\mathbf{1 9 8 0 - 1 9 8 5}$ & $-1.230(.219)$ & $1.206(.228)$ & $1.497(.134)$ \\
$\mathbf{1 9 8 5 - 1 9 9 0}$ & $-1.091(.275)$ & $1.805(.071)$ & $1.715(.086)$ \\
$\mathbf{1 9 9 0 - 1 9 9 5}$ & $.695(.487)$ & $1.295(.195)$ & $1.590(.112)$ \\
$\mathbf{1 9 9 5 - 2 0 0 0}$ & $-.434(.664)$ & $2.091(.037)^{*}$ & $1.774(.076)$ \\
\hline Sweden & & & \\
\hline & Growth rate & Migration rate in & Migration rate out \\
\hline $\mathbf{1 9 8 5 - 1 9 9 0}$ & $-.113(.910)$ & $1.022(.307)$ & $.037(.971)$ \\
$\mathbf{1 9 9 0 - 1 9 9 5}$ & $1.293(.196)$ & $.103(.918)$ & $-.936(.349)$ \\
$\mathbf{1 9 9 5 - 2 0 0 0}$ & $1.989(.047)^{*}$ & $1.093(.275)$ & $-1.595(.111)$ \\
\hline
\end{tabular}

Note: The entries are the Moran's I z-scores with the probabilities that there is no spatial autocorrelation in parenthesis. The tests are two-sided and based on row-standardized binary weighting matrices. Asterisks signify that spatial autocorrelation cannot be rejected at the 5 percent level. 
Table 4.1 GMM system estimates of regional growth, counties in Norway and Sweden

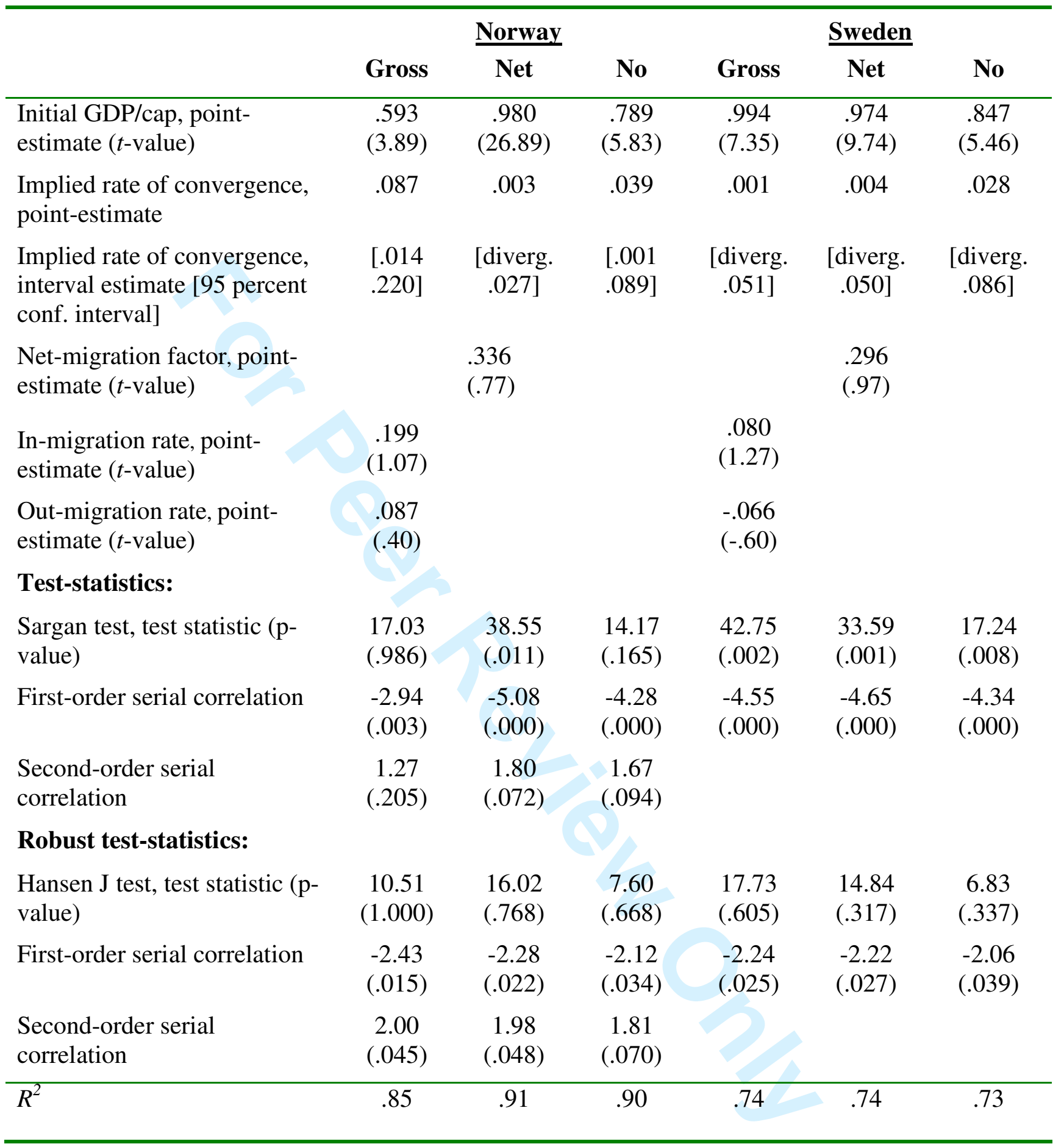

Note: The number of observations is 76 for Norway and 72 for Sweden. The dependent variable is $y_{i, t}$. The rate of convergence estimate is based on the initial GDP/cap estimate, on the assumption of Cobb-Douglas technology. The estimation procedure is the GMM system approach. The reported estimates are based on the one-step version. Standard errors are robust to heteroscedasticity within panels. Besides the lagged dependent variable, the migration rates are treated as predetermined, and instrumented. The Sargan test is a test of the validity of overidentifying restrictions that is asymptotically $\chi^{2}$. The null hypothesis that lagged levels of the endogeneous variables dated $t$-2or earlier are valid instruments in the first-differenced equation combined with first differences dated $\mathrm{t}-1$ as valid instruments in the level equation, is not rejected. The Hansen $\mathrm{J}$ test is like Sargan, but robust to heteroscedasticity. The first and second order serial correlation tests are for first differenced residuals (Arellano-Bond tests). There are not enough time series observations in the Swedish data to do the Arellano-Bond test for second order serial correlation. The model is estimated including time-specific effects. 
The $R^{2}$ reported is the $R^{2}$ of regressing predicted on actual value for the dependent variable. Estimation is performed using the software STATA 8.2 and the Xtabond2 procedure written by David Roodman. 
Table 4.2 GMM system estimates of regional growth, counties in Norway and Sweden

\begin{tabular}{|c|c|c|c|c|c|c|}
\hline & \multicolumn{3}{|c|}{$\underline{\text { Norway }}$} & \multicolumn{3}{|c|}{ Sweden } \\
\hline & Gross & Net & No & Gross & Net & No \\
\hline $\begin{array}{l}\text { Initial GDP/cap, point- } \\
\text { estimate ( } t \text {-value) }\end{array}$ & $\begin{array}{c}.831 \\
(19.99)\end{array}$ & $\begin{array}{c}.806 \\
(16.74)\end{array}$ & $\begin{array}{c}.833 \\
(16.90)\end{array}$ & $\begin{array}{c}.846 \\
(8.37)\end{array}$ & $\begin{array}{c}.934 \\
(10.18)\end{array}$ & $\begin{array}{c}.824 \\
(6.63)\end{array}$ \\
\hline $\begin{array}{l}\text { Implied rate of } \\
\text { convergence, point- } \\
\text { estimate }\end{array}$ & .031 & .036 & .030 & .028 & .011 & .032 \\
\hline $\begin{array}{l}\text { Net-migration factor, point- } \\
\text { estimate ( } t \text {-value) }\end{array}$ & & $\begin{array}{l}-.444 \\
(-.75)\end{array}$ & & & $\begin{array}{l}.166 \\
(.55)\end{array}$ & \\
\hline $\begin{array}{l}\text { In-migration rate, point- } \\
\text { estimate ( } t \text {-value) }\end{array}$ & $\begin{array}{l}-.072 \\
(-.90)\end{array}$ & & & $\begin{array}{l}.048 \\
(.76)\end{array}$ & & \\
\hline $\begin{array}{l}\text { Out-migration rate, point- } \\
\text { estimate ( } t \text {-value) }\end{array}$ & $\begin{array}{l}.078 \\
(.98)\end{array}$ & & & $\begin{array}{l}-.144 \\
(-2.02)\end{array}$ & & \\
\hline College & $\begin{array}{l}.187 \\
(3.14)\end{array}$ & $\begin{array}{l}.212 \\
(2.63)\end{array}$ & $\begin{array}{l}.176 \\
(2.85)\end{array}$ & $\begin{array}{l}.039 \\
(1.12)\end{array}$ & $\begin{array}{l}.025 \\
(.84)\end{array}$ & $\begin{array}{c}.046 \\
(1.03)\end{array}$ \\
\hline \multicolumn{7}{|l|}{ Test-statistics: } \\
\hline $\begin{array}{l}\text { Sargan test, test statistic (p- } \\
\text { value) }\end{array}$ & $\begin{array}{l}46.77 \\
(.071)\end{array}$ & $\begin{array}{l}39.13 \\
(.019)\end{array}$ & $\begin{array}{l}29.69 \\
(.003)\end{array}$ & $\begin{array}{l}44.80 \\
(.003)\end{array}$ & $\begin{array}{l}36.95 \\
(.001)\end{array}$ & $\begin{array}{l}22.65 \\
(.004)\end{array}$ \\
\hline $\begin{array}{l}\text { First-order serial } \\
\text { correlation }\end{array}$ & $\begin{array}{l}-5.44 \\
(.000)\end{array}$ & $\begin{array}{l}-5.31 \\
(.000)\end{array}$ & $\begin{array}{l}-5.28 \\
(.000)\end{array}$ & $\begin{array}{l}-4.83 \\
(.000)\end{array}$ & $\begin{array}{l}-4.57 \\
(.000)\end{array}$ & $\begin{array}{l}-4.38 \\
(.000)\end{array}$ \\
\hline $\begin{array}{l}\text { Second-order serial } \\
\text { correlation }\end{array}$ & $\begin{array}{c}2.17 \\
(.030)\end{array}$ & $\begin{array}{l}2.16 \\
(.031)\end{array}$ & $\begin{array}{c}2.09 \\
(.037)\end{array}$ & & & \\
\hline \multicolumn{7}{|l|}{ Robust test-statistics: } \\
\hline $\begin{array}{l}\text { Hansen } J \text { test, test statistic } \\
\text { (p-value) }\end{array}$ & $\begin{array}{l}13.76 \\
(.999)\end{array}$ & $\begin{array}{l}12.21 \\
(.967)\end{array}$ & $\begin{array}{l}9.93 \\
(.622)\end{array}$ & $\begin{array}{l}16.21 \\
(.805)\end{array}$ & $\begin{array}{l}16.76 \\
(.333)\end{array}$ & $\begin{array}{l}10.70 \\
(.219)\end{array}$ \\
\hline $\begin{array}{l}\text { First-order serial } \\
\text { correlation }\end{array}$ & $\begin{array}{l}-2.41 \\
(.016)\end{array}$ & $\begin{array}{l}-2.39 \\
(.017)\end{array}$ & $\begin{array}{l}-2.40 \\
(.016)\end{array}$ & $\begin{array}{l}-2.35 \\
(.019)\end{array}$ & $\begin{array}{l}-2.21 \\
(.027)\end{array}$ & $\begin{array}{l}-2.17 \\
(.030)\end{array}$ \\
\hline $\begin{array}{l}\text { Second-order serial } \\
\text { correlation }\end{array}$ & $\begin{array}{l}2.10 \\
(.036)\end{array}$ & $\begin{array}{l}2.06 \\
(.040)\end{array}$ & $\begin{array}{c}2.11 \\
(.035)\end{array}$ & & & \\
\hline$R^{2}$ & .93 & .93 & .93 & .75 & .74 & .74 \\
\hline
\end{tabular}

Note: See the note to Table 4.1 Heating degree days (Norway), frost nights (Sweden) and population density are added to the instrument list. 
Table 4.3 Regression estimates for regional migration, counties in Norway and Sweden

\begin{tabular}{lcccccc}
\hline & $\begin{array}{c}\text { Gross } \\
\text { in }\end{array}$ & $\begin{array}{c}\text { Norway } \\
\text { Gross } \\
\text { out }\end{array}$ & Net & $\begin{array}{c}\text { Gross } \\
\text { in }\end{array}$ & $\begin{array}{c}\text { Gweden } \\
\text { out }\end{array}$ & Net \\
\hline Initial GDP/cap & .055 & -.252 & .047 & -.941 & -.933 & -.002 \\
& $(.21)$ & $(-.91)$ & $(2.00)$ & $(-3.25)$ & $(-4.47)$ & $(-.04)$ \\
Employment/working age & -.424 & .181 & -.084 & 2.38 & .776 & .279 \\
capita & $(-1.72)$ & $(.71)$ & $(-3.84)$ & $(2.75)$ & $(1.24)$ & $(2.06)$ \\
College & .770 & .653 & .039 & .528 & .257 & .049 \\
& $(4.45)$ & $(3.65)$ & $(2.52)$ & $(5.62)$ & $(3.80)$ & $(3.37)$ \\
Primary share & -.045 & .027 & -.011 & .012 & -.082 & .018 \\
& $(-1.00)$ & $(.58)$ & $(-2.73)$ & $(0.19)$ & $(-1.87)$ & $(1.93)$ \\
Climate & 1.057 & 1.385 & -.053 & -.200 & -.175 & -.003 \\
& $(7.13)$ & $(9.04)$ & $(-4.03)$ & $(-1.60)$ & $(-1.95)$ & $(-.16)$ \\
Population density & .132 & .453 & -.059 & -.033 & -.116 & .015 \\
& $(.85)$ & $(2.81)$ & $(-4.24)$ & $(-0.76)$ & $(-3.69)$ & $(2.23)$ \\
\hline$R^{2}$ (Adjusted $\left.R^{2}\right)$ & $.75(.71)$ & $.72(.68)$ & $.60(.54)$ & $.49(.42)$ & $.68(.64)$ & $.66(.62)$ \\
\hline
\end{tabular}

Note: 76 observations. Pooled OLS. 